\title{
Recenzja
}

\section{Partie i system partyjny III RP, pod red. K. Kowalczyka, Wydawnictwo Adam Marszałek, Toruń 201 1, ss. 433}

Debata na temat partii politycznych jest zawsze aktualna. Odpowiada dynamice procesów politycznych, koresponduje również ze znaczącą rolą ugrupowań politycznych w życiu społecznym. W państwach Europy Środkowo-Wschodniej partie wciąż jeszcze nie osiągnęły rozwoju odpowiadającego ugrupowaniom zachodnioeuropejskim. Kultura prawna i polityczna aktorów życia społecznego, bezkompromisowe dążenie do maksymalizacji politycznych zysków utrudnia wykształcenie się dojrzałego systemu partyjnego. Większa rola oddziaływania na jego kształt przypada więc przedstawicielom nauki tak prawa ustrojowego, jak i nauk politycznych. Wypada przy tym zgodzić się z redaktorem książki Krzysztofem Kowalczykiem, że opracowanie dotyczące partii politycznych jest z reguły „zapisem chwili”, bo odnosi się do dynamicznego procesu kształtowania się systemu partyjnego, a także do przeobrażeń samych ugrupowań politycznych. Gdy dodać do tego specyfikę ustrojową systemu partyjnego państw Europy Środkowej i Wschodniej, „zapisywana chwila” wydaje się jeszcze krótsza.

Godna podkreślenia jest konieczność rozwoju życia politycznego przy współpracy socjologów, politologów i prawników. Pierwsi z nich analizując zmiany społeczne stawiają diagnozę co do zaobserwowanych i zachodzących zmian społecznych. Zadaniem politologów jest zbadać, czy i w jaki sposób partie polityczne zmianom tym sprzyjają i czy są ich katalizatorem. Rolą prawników jest oceniać istniejące ramy prawne funkcjonowania partii politycznych i przy ich pomocy stymulować rozwój systemu partyjnego i samych ugrupowań politycznych.

Recenzowana książka w pełni odpowiada zapotrzebowaniu na profesjonalne, dojrzałe, naukowe i wielopłaszczyznowe diagnozowanie sytuacji partii i systemu partyjnego Polski1. Wielowątkowość książki widać już pri-

Opracowanie nie uwzględnia zmian prawnych wynikających z wejścia w życie ustawy z dnia 5 stycznia 2011 r. - Kodeks wyborczy (Dz.U. Nr 21, poz. 112, ze zm.). 
ma facie przy lekturze spisu jej treści. Systematyka opracowania obejmuje bowiem sześć rozdziałów. Pierwszy (Organizacyjne aspekty funkcjonowania partii politycznych) oraz częściowo piąty (Partie na rynku politycznym $i$ w krajowych procesach wyborczych i mechanizmach tworzenia rząów) i szósty (Partie polityczne w unijnych procesach wyborczych $i w$ strukturach ponadnarodowych) mają albo charakter prawniczy, albo nawiązują do formalnych podstaw funkcjonowania ugrupowań politycznych. Drugą i trzecią część książki („Partyjne strategie i przywódcy” oraz „Lewica-centrumprawica”) można określić jako ściśle politologiczną; rozdział czwarty z kolei („Programowe afiliacje partii politycznych”) charakteryzuje socjologiczno-politologiczny wymiar badań. Podział treści w poszczególne części książki jest konsekwentny oraz logiczny i - co najważniejsze - oddaje złożoną optykę badań nad partiami politycznymi i systemem partyjnym. Trzeba także podkreślić, że partie polityczne państw członkowskich UE działają na płaszczyznach krajowej i europejskiej i dlatego za właściwe należy uznać wyodrębnienie problematyki unijnej do osobnego rozdziału.

Rozpoczynający prezentowaną książkę rozdział obejmuje trzy artykuły. W pierwszym K. A. Wojtaszczyk przedstawia instytucjonalizację prawną partii politycznych w Polsce. Nawiązuje do znanego Weberowskiego wyróżnienia etapów instytucjonalizacji nowoczesnych partii politycznych, uzupełniając go o catch-all party i cartell party. Szkoda, że Autor nie odniósł się szerzej do modelu cartell party koncentrując się zbytnio na trzech pierwszych weberowskich etapach instytucjonalizacji. Współczesna dyskusja nad procesem ewolucji partii proporcje te całkowicie odwraca i skupia się na profilu Keitz'a i Mair'a (catch-all party) a także Hopkina i Palucciego (business firm party). Skrótowa $\mathrm{z}$ konieczności jest także analiza stanu prawnego. Wypada ją jednak uzupełnić o, przeoczoną zapewne, ustawę z 1989 r. Prawo o stowarzyszeniach, która reguluje, przez stosowne odesłanie, procedurę likwidacji partii. Można też pokusić się o rozbudowanie części omawianego. Przykładowo interesujące wydaje się zagadnienia autonomii partii politycznych oraz jej granic.

Przedmiotem drugiego artykuł A. Jackowskiej i J. Zbieranka jest system finansowania partii w Polsce, trzon regulacji prawnej ugrupowań politycznych. Autorzy rzetelnie przedstawiają źródła finansowania partii, tytułem uzupełnienia można wskazać, że pośrednim źródłem środków finansowych dla partii są pieniądze uzyskiwane na funkcjonowanie klubów parlamen- 
tarnych. Trafne są przywołane przez Autorów pomysły zmiany struktury wydatków partii (zwłaszcza, gdy chodzi o wzrost znaczenia Funduszu Eksperckiego) i postulaty zwiększenia zasady jawności wydatkowania środków pochodzących z budżetu państwa. Bardzo interesujący jest także pomysł wprowadzenia voucherów, dysponentem których staliby się sami wyborcy. Za niepotrzebny - bo pozbawiony wartości naukowej - uważam wątek poświęcony badaniom opinii społecznej na temat finansowania partii politycznych z budżetu państwa, nie na świecie państwa, którego obywatele są zwolennikami finansowania klasy politycznej.

Niezwykle interesujące jest trzecie opracowanie autorstwa K. Sobolewskiej-Myślik. Jest ono udaną próbą syntetycznego przedstawienia cech organizacji wewnętrznych polskich partii politycznych. Tekst czyta się doskonale, jego akcenty są rozłożone proporcjonalnie do wagi omawianych problemów. Należy zgodzić się z Autorką, że nazywanie polskich partii politycznych „wodzowskimi” jest nadużyciem, a popularność tego określenia chciałoby się dodać - ma wymiar publicystyczny. Podzielam także ocenę Autorki co do dystansu, jakie partie mają względem różnych mechanizmów partycypacyjnych członków partii. Jest to jednak szerszy problem słabego rozwoju (by nie powiedzieć braku) demokracji wewnątrzpartyjnej.

Drugi rozdział książki poświęcony strategom i przywódcom partii zawiera artykuły D. Skrzypińskiego (Strategie polskich partii politycznych), M. Hartlińskiego (Przywództwo w polskich partiach politycznych) oraz J. Sielskiego (Liderzy partyjni we współczesnych polskich partiach politycznych). Ten politologiczny fragment książki należałoby uznać za obowiązkową lekturę dla partii politycznych (oraz tzw. spin doktorów, strategów partyjnych oraz liderów ugrupowań). W szczególności na uwagę zasługuje trafny skądinąd wątek o „fetyszyzacji” strategii promocyjnych partii będącej „antidotum” na słabość struktury wewnętrznej i niedostateczny poziom strategii politycznej. Niestety długo jeszcze w Polsce nie będzie nam dane doświadczyć - odwołując się do języka thatcheryzmu - politycznego ewangelizmu.

Kolejne dwa opracowania odnoszą się do tematów tylko na pozór sobie bliskich. Maciej Hartliński niezwykle profesjonalnie i dokładnie przeanalizował problem przywództwa partyjnego w Polsce. Omawiany artykuł jest bogaty w liczne przykłady i zestawienia liczbowe (wiek przywódców, liczba pełnionych przez nich kadencji), zachowuje przy tym zrozumiałą ostrożność co do wyprowadzania wniosków, które mogłyby okazać się zbyt pochop- 
ne. Jedna konstatacja jednak wydaje się możliwa do sformułowania. Wydaje się, że obecnie dochodzi do pewnego ustabilizowania pozycji liderów partyjnych, a tym samym do zmniejszenia się ich liczby w poszczególnych partiach. Koresponduje to także z tzw. candidate-centred campaining, metodą prowadzenia kampanii wyborczych spersonalizowanych wokół partyjnych przywódców.

Jerzy Sielski z kolei w artykule o liderach partyjnych zasadnie kładzie nacisk na odróżnienie przywódców od liderów partyjnych. Słusznie wyróżnia grupę autorytetów politycznych i partyjnych, których nie można zaliczać do partyjnych liderów. Mimo, że jak wskazuje sam Autor problematyka związana z liderami partyjnymi jest trudna do analizy, jego artykuł potwierdza jednak, że dobra analiza nie jest niemożliwa.

Rozdziały trzeci i czwarty obejmują łącznie osiem artykułów: T. Godlewskiego Lewica $w$ systemie partyjnym III RP, J. Wojnickiego Ugrupowania centrowe w III RP, T. Bojarowicza Partie i ugrupowania prawicowe w III RP, M. Żerkowskiej-Balas i M. Cześnika Ideologiczne pozycje oczami wyborców: samookreślenie na skali lewica-prawica w postkomunistycznej Polsce, K. Kowalczyka Rodziny partii politycznych w III RP, A. Wójcik Partie ludowe w III RP, E. Maj Partie narodowe w III RP oraz M. Marczewskiej-Rytko Wymiar populistyczny funkcjonowania partii politycznych $w$ Polsce. Nie sposób oczywiście odnieść się szczegółowo do każdego z tych opracowań. Dostarczają one niezwykłego bogactwa analiz, ukazują różnorodność partyjną, a przede wszystkim ogromny dynamizm systemu partyjnego i związanej z nim fluktuacji wyborczej. Każdy z czytelników wyprowadzi własne wnioski wspólne wszystkim opracowaniom. Propozycja moich jest następująca.

Po pierwsze, kryterium lewicowości czy prawicowości traci na wyrazistości. Jako dowód warto przywołać zjawisko blairyzmu, określane czasem mianem „trzeciej drogi”. Lewicowy premier Tony Blair łączył przecież w swej polityce gospodarcze filary „prawicowego" thatcheryzmu (wolny rynek i własność prywatną i płynące z nich korzyści dla rozwoju gospodarki) z przypisywaną lewicy wrażliwością socjalną. Można więc powtórzyć za jednym z obserwatorów życia politycznego, że tradycyjne demokratyczne partie lewicy i prawicy stały się centrolewicą i centroprawicą, i w ten sposób przestały się różnić.

Po drugie przynależność do tzw. prawicy, lewicy czy centrum ma charakter bardziej deklaratywny niż uzasadniony ideologicznie. 
Po trzecie identyfikację z i tak niezbyt wyraźną prawicowością czy lewicowością utrudniają znaczne przemiany strukturalne ugrupowań politycznych i rozdrobnienie partyjne oraz coraz modniejsze „wyłuskiwanie” polityków o przeciwnej afiliacji politycznej, by przypomnieć najgłośniejsze ostatnie transfery polityczne Zyty Gilowskiej czy Bartosza Arłukowicza.

Piąty rozdział omawianej książki zawiera cztery opracowania: M. Cichosz Bariery dostępu partii do rynku politologicznego w Polsce, A. Żukowskiego Ewolucja ordynacji wyborczych do parlamentu RP, W. Sokoła Ewolucja systemu partyjnego w latach 1989-2010 oraz W. Jednaki Partie polityczne w gabinetach koalicyjnych. Przedostatnia część książki jest niezwykle ciekawa. Każdy z artykułów w niej zawartych zasługuje na wyróżnienie. Pierwszy za doskonały obraz efemeryczności (mimo pewnych oznak koncentracji systemu partyjnego) ugrupowań politycznych w Polsce. Drugi za trafne i celne „wytknięcie” politykom skłonności do instrumentalnego wykorzystania zmian legislacyjnych w prawie wyborczym dla osiągnięcia bieżących korzyści politycznych. Artykuł W. Sokoła jest przykładem doskonałej analizy (do czego Autor zdążył nas już przyzwyczaić) systemu partyjnego w Polsce zmierzającego do systemu opartego na dużej roli dwóch głównych sił politycznych, czemu sprzyja zresztą wysoki poziom konfliktowości. Ostatnie opracowanie piątego rozdziału to próba zmierzenia się z niezwykle trudnym problemem tworzenia gabinetów koalicyjnych oraz odnalezienia motywów poszczególnych decyzji partyjnych. Ma rację Autorka stwierdzając, że nie ma jasno określonych kryteriów, na podstawie których można oddzielić wyłącznie chęć otrzymania stanowisk od chęci realizacji założeń programowych. Lektura artykułu W. Jednaki jest przyjemnością, a zarazem wyposaża czytelnika w liczne informacje i ciekawe spostrzeżenia.

Ostatni rozdział książki ma profil „europejski”. M. Kozera omawia w nim Polskie partie polityczne w elekcjach do Parlamentu Europejskiego, a W. Ziętara Polskie partie polityczne w strukturach ponadnarodowych. Po lekturze obu artykułów czytelnik dochodzi do smutnego wniosku. Wybory do PE są traktowane przez partie polityczne jako elekcja drugiej kategorii, partie zasadniczo nie angażują się w działalność partii europejskich, a polscy politycy - czego Autorzy nie mówią a co jest dopełnieniem tego obrazu - są nierzadko „wysyłani” do Strasburga nie dla pracy na rzecz Unii Europejskiej, lecz w celu wyeliminowania z bieżących krajowych działań partyjnych. 
Wśród wielu zalet książki największą jest próba kompilacji teorii funkcjonowania partii politycznych z praktyką działania ugrupowań politycznych. Liczne w książce zestawienia tabelaryczne, numeryczne i statystyczne, a także wykresy są graficznym dowodem na to zestawienie. Recenzowana książka może i powinna zostać zaliczona do kanonu obowiązkowej lektury wszystkich interesujących się partiami politycznymi w Polsce.

Redaktor naukowy K. Kowalczyk uprzedza we wstępie, że treść omawianego opracowania jest „zapisem chwili”. Istotnie przyszłość partii nie jest łatwa do określenia. Do takiej tezy skłania nie tylko treść omawianej książki, ale także obserwacja funkcjonowania partii we Włoszech i w Grecji oraz debata tocząca się w Hiszpanii przy okazji wyborów parlamentarnych, w których zapewne zwycięży Mariano Rajoy. Otóż w sytuacji głębokiego kryzysu partie z łatwością sięgają do tzw. technokratów (czy tzw. rządów fachowców). Nie jestem pewien, czy nie jest to przypadkiem próba ucieczki i czy powtarzana wielokrotnie teza "nie ma demokracji bez partii politycznych" nie dozna wyjątków.

Jarosław Sułkowski (Uniwersytet Łódzki) 